\title{
Effect of Stromal Vascular Fraction on Fracture Healing with Bone Defects by Examination of Bone Morphogenetic Protein-2 Biomarkers in Murine Model
}

\author{
Respati S. Dradjat, Panji Sananta*(i), Rizqi Daniar Rosandi, Lasa Dhakka Siahaan (D) \\ Department of Orthopaedic and Traumatology, Faculty of Medicine, Universitas Brawijaya, RSUD Dr. Saiful Anwar, Malang, \\ Indonesia
}

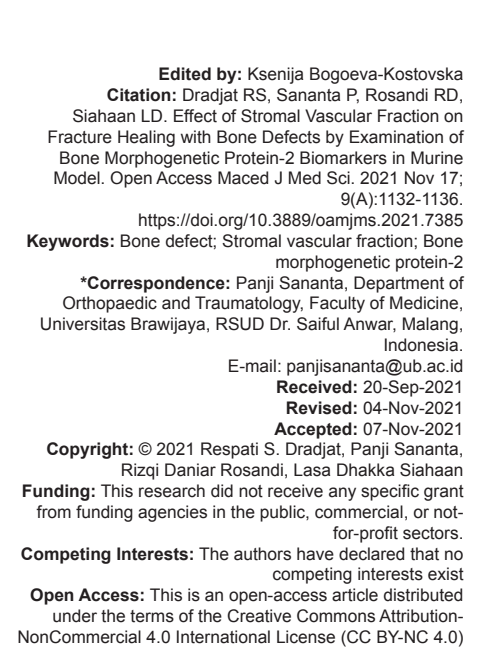

\begin{abstract}
BACKGROUND: Fractures and segmental bone defects are a significant cause of morbidity and a source of a high economic burden in healthcare. A severe bone defect ( $3 \mathrm{~mm}$ in murine model) is a devastating condition, which the bone cannot heal naturally despite surgical stabilization and usually requires further surgical intervention. The stromal vascular fraction (SVF) contains a heterogeneous collection of cells and several components, primarily: MSCs, HSCs, Treg cells, pericytic cells, AST cells, extracellular matrix, and complex microvascular beds (fibroblasts, white blood cells, dendritic cells, and intra-adventitial smooth muscular-like cells). Bone morphogenetic protein (BMP) is widely known for their important role in bone formation during mammalian development and confers a multifunctional role in the body, which has potential for therapeutic use. Studies have shown that BMPs play a role in the healing of large size bone defects.
\end{abstract}

AIM: In this study, researchers aim to determine the effect of administering SVF from adipose tissue on the healing process of bone defects assessed based on the level biomarker of BMP-2.

MATERIALS AND METHODS: This was an animal study involving 12 Wistar strain Rattus norvegivus. They were divided into three groups: Negative group (normal rats), positive group (rats with bone defect without SVF application), and SVF group (rats with bone defect with SVF application). After 30 days, the rats were sacrificed; the biomarkers that were evaluated are BMP-2. This biomarker was quantified using ELISA.

RESULTS: BMP-2 biomarker expressions were higher in the SVF application group than in the group without SVF. All comparisons of the SVF group and positive control group showed significant differences $(p=0.026)$.

CONCLUSION: SVF application could aid the healing process in a murine model with bone defect marked by the increased level of BMP-2 as a bone formation marker.

\section{Introduction}

Fractures and segmental bone defects are a significant cause of morbidity and a source of a high economic burden in health care. A severe bone defect is a devastating condition in which the bone cannot heal naturally despite surgical stabilization and usually requires further surgical intervention, such as stem cell or stromal vascular fraction (SVF) application [1]. Bone defects ( $3 \mathrm{~mm}$ in murine model [2]) remain a challenge for orthopedic surgeons. These conditions often complicate the fracture and require additional reconstructive procedures, such as bone transport, acute limb shortening and lengthening, massive allograft or vascularized fibular allograft, masquelet technique (induced membrane), and bone grafting with bone morphogenetic protein (BMP). Extensive and segmental bone defects do not require salvage action, and despite these efforts, there is an excellent long-term functional outcome but is limited by high complications and reoperation [3], [4].
SVF is a heterogeneous cell population that arises from minimally manipulated adipose tissue. It has been reported that SVF contains various cells such as adipose-derived mesenchymal stem cells (ADMSC), hematopoietic stem cells (HSC), T-regulatory cells (T-reg), and progenitor cells. SVF also contains growth factors such as insulin-like growth factor-1 (IGF-1), transforming growth factor $\beta$ (TGF- $\beta$ ), and fibroblast growth factor (FGF), which plays a role in cell proliferation and differentiation [4], [5].

The healing process in bone defect goes through several phases: Hematoma formation, inflammation, soft callus formation in the cartilage, neovascularization, soft callus mineralization, hard callus formation, and remodeling of the osteoclastic hard callus [6], [7]. This process, however, is not enough to cover large defects in bones. Under the circumstances, an autograft is a preferred method to replace bone loss. During the healing process of bone defect, several biomarkers fluctuate dynamically to signify an ongoing bone formation, such as BMP-2 and osteocalcin [8]. During the bone formation process, the levels of these biomarkers mentioned 
above will elevate, thus making them a good parameter for evaluating fracture healing with a bone defect [8].

BMPs are widely recognized for their essential role in bone formation during mammalian development and confer a multifunctional role in the body, which has potential for therapeutic use. Studies have shown that BMPs play a role in the healing process of large size bone defects. There are many isoforms of BMP, including BMP-1, BMP-2, and several other BMP isoforms. However, only BMP-2 is essential for the osteogenic process, with BMP-2 and BMP-7, approved for clinical use in healing major bone defects [8].

The benefit of SVF application in the medical and orthopedics field has been widely observed. SVF has been used in cases of burnt trauma, nerve injury, osteoarthritis, osteonecrosis, rheumatoid arthritis, rupture of the Achilles tendon, and growth plate defect [9], [10], [11]. Many SVF applications in bone defect therapy have been made, but there has been no study that measures the effect of SVF application on bone healing from BMP-2 biomarker. Hence, in this study, the authors would like to observe the effect of SVF from adipose tissue in the healing process of bone defect, measured by the BMP-2 biomarker.

\section{Materials and Methods}

\section{Study design and animal model}

The research design used was an experimental laboratory method with a randomized post-test only control group design. In this study, the parameters measured were the effect of SVF in increasing the osteogenic and osteoinductive activity of fracture regeneration with bone defects with BMP-2 as an indicator.

The study started by selecting rats that met the inclusion and exclusion criteria acclimatized for 7 days, then randomly divided into three groups: The negative group is normal rats without fracture and large-sized bone defect and SVF application. The positive group is the murine model with fracture and large-sized bone defect but without SVF application. The SVF group is the murine model with fracture and large-sized bone defect and SVF application. These three groups will be observed for 30 days and tested for biomarker levels of BMP-2.

\section{Study procedures}

Maintenance and treatment of the murine models in the form of making fracture models with bone defects accompanied by the provision of SVF were carried out in the animal lab of Universitas Brawijaya Faculty of Medicine. The making of SVF and the application of SVF were carried out at the physiology laboratory of Universitas Brawijaya Faculty of Medicine.
At the same time, BMP-2 biomarker was examined in the biomedical laboratory of Universitas Brawijaya Faculty of Medicine. The Ethics Committee of Universitas Brawijaya Faculty of Medicine has approved all animal protocols, and all subsequent experiments were carried out according to the relevant guidelines and regulations.

\section{The making of SVF from adipose tissue}

Five 12-week-old male Wistar strain rats were sacrificed by dislocating their cervical spine. The rats were positioned in a supine position. A skin incision was made to expose the abdomen. The testicles were removed, and the fat surrounding them was harvested. Adipose tissue was harvested from the epididymal and perirenal fat. The perirenal fat was collected by cutting off the innervation from the retroperitoneal fat pad.

The harvested adipose tissue was then washed with a solution of PBS (Phosphate-buffered saline; Sigma-Aldrich, Germany) which contains a mixture of $10 \%$ antibiotic-antimycotic, then mashed with a knife. It was then immersed in a $0.075 \%$ type IA collagenase mixture (Sigma-Aldrich) and PBS for $30 \mathrm{~min}$ at $37^{\circ} \mathrm{C}$. The processed tissue was then strained with a $100 \mu \mathrm{m}$ mesh (Sigma-Aldrich) and centrifuged at $1200 \mathrm{rpm}$ for $10 \mathrm{~min}$ at $20^{\circ} \mathrm{C}$. The supernatant was discarded, and the resulting suspension yielded a heterogeneous cell mixture with an estimate of $2 \times 10^{6}$ cells for $1 \mathrm{~g}$ of adipose tissue [12].

\section{Preparation procedure for animal fracture model with bone defect and plaster of Paris application}

Murine models were acclimatized for 7 days before a bone defect was made on rats in positive and intervention groups. Before the procedure, the murine models were anesthetized with $100 \mathrm{mg} / \mathrm{kg}$ ketamine injection and intraperitoneal $10 \mathrm{mg} / \mathrm{kg}$ xylazine hydrochloride. The authors ensured that rats were under anesthesia using the pedal reflex technique by extending the extremities and pinching the web between the toes. If murine shied away or twitched a muscle and made a sound, the anesthesia was not enough. After that, an antibiotic injection of $20 \mathrm{mg} / \mathrm{kg}$ cefazolin was administered on the right leg. The operating area was then shaved and cleaned with chlorhexidine. The murine were placed in a prone position on the operating area and incised for 3-4 cm, deepening the incision layer by layer until the bone was exposed. Osteotomy was done using a $3 \mathrm{~mm}$ Kerrison, so the bone defect made was $3 \mathrm{~mm}$ wide. The intervention was then done according to the assigned groups. Then, Plaster of Paris was applied from the proximal femur to the ankle with a $90^{\circ}$ flexion of the knee. Analgesia was given every $8 \mathrm{~h}$ (using IM $5 \mathrm{mg} / \mathrm{kg}$ Ketorolac), and an antibiotic was administered $24 \mathrm{~h}$ post-surgery using intramuscular $20 \mathrm{mg} / \mathrm{kg}$ cefazolin. Monitoring was done periodically for 30 days. 


\section{Laboratory analysis with ELISA method}

After 30 days, murine models were harvested. The area of bone defect with callus formation was collected and then extracted. The levels of BMP-2 were assessed using the ELISA method.

\section{Statistical analysis}

The steps of hypothetical comparative test are as follows: Data normality test, variant homogeneity test, and comparative Student T-test or one-way ANOVA test or Kruskal-Wallis test according to the normality and homogeneity test result. If ANOVA or Kruskal-Wallis test result is significant $(p<0.05)$, then the next test is the post hoc test. If the data collected were not homogenous by ANOVA, a non-parametric test with the Kruskal-Wallis method can be done.

\section{Results}

The BMP-2 level was measured using an ELISA reader. The results are depicted in Table 1.

Table 1: Serum BMP-2 level measurement

\begin{tabular}{lc}
\hline Treatment group & BMP-2 \\
\hline P1 (-) & 293.239 \\
P2 (-) & 206.118 \\
P3 (-) & 256.837 \\
P4 (-) & 141.823 \\
P1 (+) & 239.016 \\
P2 (+) & 210.354 \\
P3 (+) & 280.801 \\
P4 (+) & 192.198 \\
P1 SVF & 350.591 \\
P2 SVF & 300.966 \\
P3 SVF & 311.585 \\
P4 SVF & 321.456 \\
\hline BMP: Bone morphogenetic protein, SVF: Stromal vascular fraction
\end{tabular}

The BMP-2 comparative hypothesis test in each treatment group was carried out by ANOVA test because the data were normally distributed and homogenous. Table 2 shows the results of the comparative test.

Table 2: ANOVA comparative hypothesis test result

\begin{tabular}{llc}
\hline Group & Mean \pm SD & $p$-value \\
\hline Negative & $224.5043 \pm 65.6864^{\mathrm{a}}$ & \\
Positive & $230.5923 \pm 38.6246^{\mathrm{a}}$ & 0.026 \\
SVF & $321.1495 \pm 21.3366^{\mathrm{b}}$ & \\
\hline On average \pm SD if it contains different letters $(\mathrm{a}-\mathrm{b})$ it means that there is a significant difference $(\mathrm{p}<0.05)$ \\
and if it contains the same letters $(\mathrm{a}-\mathrm{a})$ it means that there is no significant difference $(p>0.05) . S V F:$ \\
Stromal vascular fraction
\end{tabular}

Based on the analysis results using ANOVA, the test result is a $p$-value of 0.026 , smaller than $=0.05$ $(p<0.05)$. So from this test, it can be concluded that there is a significant effect of giving SVF to BMP-2 levels. In other words, there is a significant difference in BMP-2 levels due to the application of SVF. Table 3 is the results of the post hoc test to determine the differences in each treatment.
Table 3: Post hoc analysis on SVF application related BMP serum

\begin{tabular}{lll}
\hline Groups comparison & p-value & Notes \\
\hline Negative & & \\
$\quad$ Positive & 0.981 & Not significantly different \\
SVF & 0.037 & Significantly different \\
Positive & & \\
$\quad$ Negative & 0.981 & Not significantly different \\
SVF & 0.049 & Significantly different \\
SVF & & \\
$\quad$ Negative & 0.037 & Significantly different \\
Positive & 0.049 & Significantly different \\
\hline SVF: Stromal vascular fraction. & &
\end{tabular}

Based on the post hoc test results above, the treatment groups have a significantly different mean value if the $p$-value is less than $0.05(p<0.05)$ and if the $p$-value is more than $0.05(p>0.05)$, then the treatment groups have an average value that is not significantly different. Therefore, based on the data above, the SVF application significantly affects the positive group. The average BMP-2 expression in each group is shown in the following histogram (Figure 1):

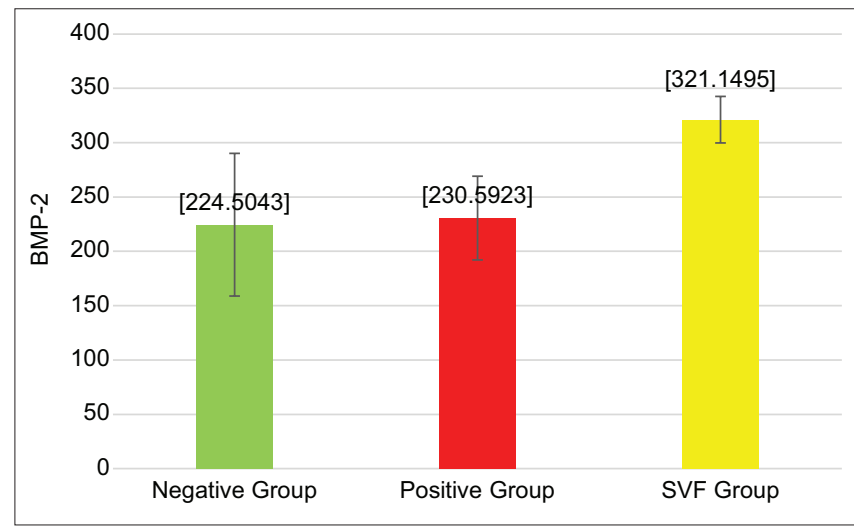

Figure 1. Histogram of average BMP-2 based on each group. BMP: Bone morphogenetic protein

\section{Discussion}

Adipose tissue has long been considered useless tissue, and for many years fat tissue has become a "waste material" from surgical procedures, especially plastic surgery. Recently, it has been recognized that adipose tissue is an abundant, practical, and attractive resource as donor tissue in autologous cell replacement. SVF was first described in 1960 by Hollenberg, and it was found in 2001 that SVF contains a large number of mesenchymal stem cell (MSCs) [13], [14].

The SVF has several advantages over other biologically active materials. These advantages include (1) The patient's discomfort can be minimized when fat tissue is taken, (2) contains a high ratio of stem cell volume, (3) tissue extraction is relatively easy and can be adjusted to the needs, (4) process of processing fat tissue into ADMSCs which then becoming SVF with 
the high mesenchymal cells can be done quickly, and (5) the multipotent cells contained in SVF can bind quickly to the scaffold material, increase quickly, and can differentiate into osteogenic elements [15,] [16].

SVF is a heterogeneous cell population derived from adipose tissue obtained from minimal manipulation of the adipose tissue itself. It has been previously reported that these SVFs contain diverse cells consisting of ADMSCs, HSCs, T-reg cells, pericytic cells, and other progenitor cells. In addition, SVF also contains many growth factors, in this case, IGF1, FGF2, and TGF- $\beta$ [17].

Discovered more than 50 years ago as an induction agent for de novo bone formation, BMPs are now recognized as the most efficient family of growth factors in assisting the healing of large bone defects. However, only BMP-2 has been shown to be essential for the osteogenic process, with BMP-2 and BMP-7 are approved for clinical use in healing major bone defects [8].

In this study, there was a significant difference in the levels of BMP-2 after application of SVF, respectively, $(p=0.026)$ compared to control (positive) group and confirmed with post hoc test also shows that there is a significantly different effect from SVF group to positive group. That implies that the SVF application will increase the level of BMP-2 in fractures with bone defects because the function of BMP-2 is to differentiate progenitor cells into osteoblasts. Because of the higher the level of BMP-2, the greater the number of osteoblasts that play a role in bone formation would increase, therefore showing a superior fracture healing process. We suggest further study to use a combination of SVF and scaffold and use a different fixation such as an external fixation or an internal fixation to expand the study toward various modalities used in orthopedics fields.

\section{Conclusion}

From this study, the application of SVF could aid healing processes in murine models with bone defects marked by increased levels of BMP-2 as a bone formation marker.

\section{Authors Contributions}

Study Design: Respati S. Dradjat, Panji Sananta, Rizqi Daniar Rosandi, and Lasa Dhakka Siahaan. Data Collection: Respati S. Dradjat, Panji Sananta, and Rizqi Daniar Rosandi. Statistical
Analysis: Respati S. Dradjat, Panji Sananta, Rizqi Daniar Rosandi, and Lasa Dhakka Siahaan. Data Interpretation: Respati S. Dradjat, Panji Sananta, Rizqi Daniar Rosandi, and Lasa Dhakka Siahaan. Manuscript Preparation: Respati S. Dradjat, Panji Sananta, Rizqi Daniar Rosandi, and Lasa Dhakka Siahaan. Literature Search: Panji Sananta, Rizqi Daniar Rosandi, and Lasa Dhakka Siahaan. Funds Collection: This research did not receive any specific grant from funding agencies in the public, commercial, or not-for-profit sectors.

\section{References}

1. Perez JR, Kouroupis D, Li DJ, Best TM, Kaplan L, Correa D. Tissue engineering and cell-based therapies for fractures and bone defects. Front Bioeng Biotechnol. 2018;6:105. https://doi. org/10.3389/fbioe.2018.00105

PMid:30109228

2. Kim JH, Kim HW. Rat defect models for bone graft and tissue engineered bone constructs. Tissue Eng Regen Med. 2013;10:31-6. https://doi.org/10.1007/s13770-013-1093-x

3. Adamczyk A, Meulenkamp B, Wilken G, Papp S. Managing bone loss in open fractures. OTA Int. 2020;3(1):e059. https:// doi.org/10.1097/OI9.0000000000000059 PMid:33937684

4. Roato I, Belisario DC, Compagno M, Verderio L, Sighinolfi A Mussano $\mathrm{F}$, et al. Adipose-derived stromal vascular fraction/ xenohybrid bone scaffold: An alternative source for bone regeneration. Stem Cells Int. 2018;2018:4126379. https://doi. org/10.1155/2018/4126379

PMid:29853912

5. Alexander RW. Understanding adipose-derived stromal vascular fraction (AD-SVF) cell biology and use on the basis of cellular, chemical, structural and paracrine components: A concise review. J Prolother. 2012;4(1):e855-69.

6. Kheirallah M, Almeshaly $\mathrm{H}$. Present strategies for critical bone defects regeneration. Oral Health Case Rep. 2016;2:3.

7. Kamal AF, Iskandriati D, Dilogo IH, Siregar NC, Hutagalung EU, Susworo R, et al. Biocompatibility of various hydoxyapatite scaffolds evaluated by proliferation of rat's bone marrow mesenchymal stem cells: An in vitro study. Med J Indones. 2013;22(4):202-8.

8. Chen G, Deng C, Li YP. TGF- $\beta$ and BMP signaling in osteoblast differentiation and bone formation. Int $\mathrm{J}$ Biol Sci. 2012;8(2):272-88. https://doi.org/10.7150/ijbs.2929 PMid:22298955

9. Gentile P, Piccinno MS, Calabrese C. Characteristics and potentiality of human adipose-derived stem cells (hASCs) obtained from enzymatic digestion of fat graft. Cells. 2019;8(3):282. https://doi.org/10.3390/cells8030282 PMid:30934588

10. Rodriguez JP, Murphy MP, Hong S, Madrigal M, March KL, Minev B, et al. Autologous stromal vascular fraction therapy for rheumatoid arthritis: Rationale and clinical safety. Int Arch Med. 2012;5(1):5. https://doi.org/10.1186/1755-7682-5-522313603 PMid:22313603

11. Sananta P, Oka RI, Dradjat PR, Suroto H, Mustamsir E, Kalsum U, et al. Adipose-derived stromal vascular fraction prevent bone bridge formation on growth plate injury in rat (in vivo studies) an 
experimental research. Ann Med Surg (Lond). 2020;60:211-7. https://doi.org/10.1016/j.amsu.2020.09.026

PMid:33194176

12. Zuk P. Adipose-derived stem cells in tissue regeneration: A review. ISRN Stem Cells. 2013;2013:713959. https://doi. org/10.1155/2013/713959

13. Bora P, Majumdar AS. Adipose tissue-derived stromal vascular fraction in regenerative medicine: $A$ brief review on biology and translation. Stem Cell Res Ther. 2017;8(1):145. https://doi. org/10.1186/s13287-017-0598-y

PMid:28619097

14. Levi B, Longaker MT. Concise review: Adipose-derived stromal cells for skeletal regenerative medicine. Stem Cells. 2011;29(4):576-82. https://doi.org/10.1002/stem.612 PMid:21305671

15. Todorov A, Kreutz M, Haumer A, Scotti C, Barbero A,
Bourgine PE, et al. Fat-derived stromal vascular fraction cells enhance the bone-forming capacity of devitalized engineered hypertrophic cartilage matrix. Stem Cells Transl Med. 2016;5(12):1684-94. https://doi.org/10.5966/sctm.2016-0006 PMid:27460849

16. Prins HJ, Schulten EA, Ten Bruggenkate CM, Klein-Nulend J, Helder MN. Bone regeneration using the freshly isolated autologous stromal vascular fraction of adipose tissue in combination with calcium phosphate ceramics. Stem Cells Transl Med. 2016;5(10):1362-74. https://doi.org/10.5966/ sctm.2015-0369

PMid:27388241

17. Kozhemyakina $E$, Lassar AB, Zelzer E. A pathway to bone: Signaling molecules and transcription factors involved in chondrocyte development and maturation. Development. 2015;142(5):817-31. https://doi.org/10.1242/dev.105536

PMid:25715393 